\title{
Zanzibar and the Establishment of Blue Economy Strategies
}

\author{
Hafidh Ali Hafidh ${ }^{{ }^{*}}$ Saada Mkuya ${ }^{2}$ \\ 1.International School of Zanzibar: P. O. Box 1787, Zanzibar-Tanzania \\ 2.Ministry of the First Vice President of Zanzibar,
}

\begin{abstract}
Zanzibar prosperity is created, not inherited. It does not grow out of a country's natural endowments, oceanbased economy, its labor pool, its enabling environment and presence of good policy, legal and institutional frameworks as the blue economy insists. A country rapid economic growth accompanied with promotion and protection of the strategies planned to obtain sustainable development.In 2021 Government adopted a comprehensive roadmap for the development of its blue economy policy 2020 and Zanzibar Development Vision 2050 focus to Zanzibar's efforts in the blue economy over the next 30 years. This paper gives a brief description of the Zanzibar's Blue Economy and discusses some of the key blue economy frameworks. However, the aim of the paper is to look at the contemporary situation in Zanzibar in the context of the Blue Economy and its frameworks through effective initiatives done by the Zanzibar Government. Effective implementation of panned strategies will play the major role for obtaining sustainable economic development in Zanzibar. Finally, the paper provides recommendations towards a sustainable blue economy in Zanzibar.
\end{abstract}

Keywords: Blue economy, Policy, Legal, Institutional framework, Zanzibar

DOI: $10.7176 / \mathrm{JRDM} / 74-05$

Publication date:March $31^{\text {st }} 2021$

\section{Introduction}

The ocean has and will always be fundamental to our existence. Our ocean is naturally endowed with numerous resources that are valuable to mankind. The oceans mean vastness and opportunities to many people in the world. From that perspective, blue waters of the oceans are deemed as the bloodstream of this planet earth (Rahman Mohammad, 2017).

Oceans cover roughly two-thirds of our earth's surface, and contribute to poverty reduction by creating sustainable livelihoods and jobs, food, generating oxygen, absorbing greenhouse gases and mitigating the impacts of climate change, determining weather patterns, and providing international trade routes (World Bank, 2017). It is important to note that oceans are reaching a tipping point on many fronts, from overfishing and marine pollution to coastal erosion, which is exacerbated by climate change. Healthy oceans provide jobs and food, drive economic growth and keep the planet from overheating (Mulazzani et al., 2016).

The oceans are recognized as a vital repository and supporter of global biological diversity, and are a critical source of food through fisheries and aquaculture and are fundamental to the global economy through seaborne trade (Warner and Schofield, 2012). With an estimated 80\% of the volume of world trade carried by sea, international shipping and ports provide crucial linkages in global supply chains and are essential for the ability of all countries to gain access to global markets (UNCTAD, 2014).

The ocean is an essential part of the world economy - from the uses made of ocean space, the social and economic values we attach to it, the important goods and services it supplies, to the activities it supports. Despite the fact that oceans are a precious aspect of our natural heritage, only $7 \%$ of the planet's oceans have been explored (Toropova et al., 2010). Many small island developing states have jurisdiction over globally significant ocean areas, which typically far exceed their terrestrial footprint and are therefore dependent to a large extent on ocean resources and the sectors they support. Coastal and island nations, both large and small, are increasingly looking to their marine waters to bolster slowing growth in their terrestrial economies by exploring new opportunities for investment and employment.

The potential linkages between the blue economy, sustainable development and economic growth is recognized in the 2030 Agenda for Sustainable Development. SDG target 14.7 focuses on enhancing the economic benefits to Small Island Developing States (SIDS) and Least Developed Countries (LDCs) from the sustainable use of marine resources, including through the sustainable management of fisheries, aquaculture, and tourism. SIDS have been at the forefront of the blue economy advocacy, recognizing that oceans have a key role to play in humanity's future and that the blue economy offers an approach to sustainable development better suited to their circumstances, constraints and challenges(UNDP 2018).

The Indian Ocean region includes 28 coastal States and is home to a third of the world's population (Voyer, M. et al. 2018). According to the UN Resolutions, countries with coastal regions have the right to exploit whichever opportunities they can avail of in the ocean, including mining and fishing (United Nations Convention for the Law of the Sea [UNCLOS] Article 56). Another UN article gives countries with coastlines the right to mine or explore the sea and use its resources (UNCLOS Article 77). Almost all of the world's countries that 
have coastlines are launching campaigns requesting to extend their continental limits to exploit more resources. This proves that countries have understood the potential of the blue economy and that the situation is expected to improve in the near future. One theory is to put mechanisms in place to share the exploited resources with landlocked countries. This will give equal opportunities to all nations in relation to the blue economy (Schoolmeester et al., 2009).

The term 'Blue Economy' has increasingly become popular all over the world in the past decade, since it's emanation at the 2012 United Nations Convention on Sustainable Development (UNCSD), or Rio +20 Conference. Since that time there has been increasing interest in the concept of the Blue Economy around the world, yet the term is still employed differently in different contexts and there is no one universally accepted definition of what the Blue Economy is (Keen, Schwarz, \& Wini-Simeon, 2017), but those who define the blue economy they came into consensus on three aspects: increasing economic growth, conserving marine and coastal environment and maritime security.

The term 'Blue Economy' has been used in different ways and similar terms such as "ocean economy" or "marine economy" are used without clear definitions. In a concept paper, the United Nations offered general definition of the "Blue Economy" as an ocean economy that aims at "the improvement of human well-being and social equity, while significantly reducing environmental risks and ecological scarcities (UN, 2014, p.2)"

Blue Economy goals across the Indian Ocean commonly involve all these aspects; the development of the ocean space to achieve economic, developmental and socio-cultural benefits (Subhan, A. 2018). These benefits are important in combating poverty, addressing broader human security issues and ensuring regional stability. Blue Economy goals must, however, be achieved 'in a sustainable, stable and inclusive manner. The main objectives of Blue Economy are full employment level and growth of the GDP (Fernández 2016).

Meanwhile, to some Blue Economy is the integration of all maritime activities with focus on Ocean Management. Blue Economy is applicable in different contexts and range of economic policies and sectors that ensures the utilization of oceanic resources are sustainable.

\section{IDENTIFYING CURRENT STATUS OF THE BLUE ECONOMY IN ZANZIBAR}

Zanzibar consists of the Islands of Unguja and Pemba and all small Islands surrounding them and includes the territorial waters that before the Union formed the then People's Republic of Zanzibar (The Constitution of Zanzibar, 1984). More remarkably, Zanzibar as part of the United Republic of Tanzania (URT) is located in the Indian Ocean Rim with a long coastline and vast ocean resources.

Zanzibar has many surrounding Islands and low lying, and have no access to fresh water. The Islands are also the sites of extensive coral reefs, which surround the shoreline of both islands and many islets. The islands have important forests, including mangroves. Zanzibar marine and terrestrial areas support many livelihoods and provide critical ecosystem services, being the location for key endemic island flora and fauna. They provide breeding, nursery and feeding habitat for fish and shellfish, including prawns, lobsters and mud-crabs (O’Sullivan, 2005).

Zanzibar as an oceanic economy has a suitable geographical profile to utilize the blue economy potentials in consideration of Zanzibar's economy. Thus, it is logical for Zanzibar to develop appropriate plans, policies, strategies and practical initiatives that embrace the concept of a "blue economy" by viewing oceans as "development spaces". The process includes coordinated plans that integrate key strategic sectors in terms of environmental conservation, ecological frameworks, innovation skills, entrepreneurship, digitization and economic outcomes (i.e. tourism, mariculture, marine transport and environmental friendly oil and mineral wealth extraction activities) with the focus of accelerating sustainable development.

The Revolutionary Government of Zanzibar (RGoZ) has started to embed the blue economy concept among top national Agendas and regards it as an effective way for achieving sustainable development through rapid and inclusive economic growth. It is very clear that the issues related to the blue economy are among the important areas which attract national, regional and international attention. These areas are key aspects in achieving all forms of development in any nation. Indeed, there is a need for identification, description, as well as creation of monitoring and evaluating frameworks (thorough analysis of strengths, weaknesses, opportunity and challenges) to ensure that marine resources play an expected significant role in contributing towards the socio-economic welfare of the country.

The Zanzibar Development Vision 2020 has articulated the overall development goal for Zanzibar as the eradication of absolute poverty and the attainment of sustainable human development. The Vision's policy on fisheries is to strengthen the management of marine and coastal resources to support sustainable tourism development while conserving the richness of the environment. The Vision also recognizes the key role played by the fishery sector in the social and economic development of the country. On the other hand, the RGoZ has liberalized its policies to make Zanzibar a good environment for foreign investment.

Zanzibar has unveiled its Development Vision 2020-2050 and blue economy was mentioned as an important emerging economy to be implemented in the country, with the aim of tapping into the sustainable use 
of ocean resources for sustainable economic growth. Currently Zanzibar has started harnessing the blue economy by establishing different initiatives, and by doing so it has kicked off with construction of three new ports and purchase of modern boats and so on. The existing Zanzibar blue economy policy 2020 has witnessed the readiness of Zanzibar engaging in an ocean-based economy.

Due to its geographical positioning, Zanzibar has a huge number of ocean opportunities associated with a blue economy which could be utilized to foster sustainable development through environmental conservation and sustainably use the oceans, seas, marine, and coastal resources ecosystem reservation, digitization improvement, innovation enhancement and employment creation. Zanzibar has the potential to develop a thriving blue economy backed by the effective and sustainable exploitation of marine resources and related areas through the development of a competitive advantage in fisheries and aquaculture, coastal and marine tourism, marine trade and infrastructure as well as oil and gas (Zanzibar Development Vision 2050).

Therefore, the blue economy has a great potential to contribute to higher and faster GDP in Zanzibar. Innovation and growth in the coastal, marine and maritime sectors could deliver food, energy, transport, among other products and services and serve as a foundation for sustainable development in Zanzibar.

\section{OBJECTIVES OF THE POLICY PAPER}

The objective of this paper is to analyze the Zanzibar and the Establishment of Blue Economy.

\section{METHODS AND SCOPE OF RATIONALE}

This paper is based on synthesis of secondary information. To collect secondary data, an intensive literature reviews related to the coastal and marine resources and their management issues and constraints were conducted through the online search. The paper is also grounded with explanatory design.

A general review of Zanzibar's historical development of different policies related to the blue economy can bring out this new model of blue economy development. This can help us to better understand the trajectories through which Zanzibar had to move, requiring skills and care for its policies.

According to the background on Zanzibar ocean-based economy explained in the study. This helps us to trace the origin and the evolution of policy expression by the state. Through this process the transition from Zanzibar's concept of ad hoc and fragmented ocean's economy to blue economy is located in the paper. Zanzibar provides the strongest case study to examine this new model of sustainable marine development.

\section{POLICY, LEGAL AND INSTITUTIONAL FRAMEWORKS FOR THE BLUE ECONOMY}

The 1982 United Nations Convention on the Law of the Sea (UNCLOS) is the overarching international law instrument for the oceans, as it defines rights and obligations of states within their maritime spaces, and includes provisions for marine environmental protection and the management of its resources.

African Regional policy instruments such as Africa's Integrated Maritime Strategy 2050 (AIMS) (African Union 2012), the Decade of African Seas and Oceans (2015-2025), the recent Africa Blue Economy: A Policy Handbook and the African Charter on Maritime Security and Safety and Development (the Lomé Charter), demonstrate growing interest in Blue Economy as a pathway for sustainable development in Africa. They highlight the need for regional coordination and cooperation including addressing trans-boundary blue economy issues such as maritime security or trade, as well as the value of pooling resources to achieve common objectives, for example, in disaster risk reduction as well as research and development.

The African Union and the UN Economic Commission for Africa have also prioritized the Blue Economy, and have created policies aimed at promoting cooperation between Eastern African nations and their BE activities in the Western Indian Ocean (United Nations Economic Commission for Africa, 2016). In particular, the African Union (AU) plays a crucial role in developing and implementing the Blue Economy Policy and Strategy in the African region. Over the past decade, the African Union Commission (AUC) has built an enlarged Africa-wide consensus regarding the critical role that the Blue Economy could play in fostering structural transformation in Africa during the next decade. This is encapsulated in the African Union's 2050 Africa's Integrated Maritime Strategy (AU 2050 AIMS), which describes the Blue Economy as the "new frontier of African Renaissance."

There is a need to adhere such policy, legal and institutional frameworks due to the increase in environmental degradation, the effects of climate change and population growth. The existence of such systems will be able to manage marine resources in the Indian Ocean and its shores, so in that context there is a need for the establishment of appropriate national laws, policies and institutional frameworks.

The fact that the Blue Economy is a cross cutting topic span spanning across a number of different sectors, with significant potential synergies, provides positive incentives for moving toward better integrated legal, regulatory, and institutional frameworks. Therefore, it is an essential fact to formulate a strategic framework and create an enabling environment as a roadmap towards the prosperous future of Zanzibar. 


\subsection{IMPLICATION OF BLUE ECONOMY POLICY IN ZANZIBAR}

Zanzibar has started in exploiting the opportunities available in the marine resources as a Blue Economy needs to develop policy, legal and institutional frameworks to benefit from the status of development and political agendas. From a legal perspective, the challenges of controlling the use of the ocean and managing it are important aspects, especially in combating those who violate maritime law, since the legal landscape is relevant to the ocean management as well as selected national law and policy approaches.

The Zanzibar Development Vision 2050 regards the Blue Economy as a priority area for the next 30 years, serving as an effective and sustainable means of improving livelihoods and transforming the country's economy. The Blue Economy policy has thus been developed as a guiding framework for the implementation of the seabased economy for the coming decade. Zanzibar can harness the potential of the blue economy by ensuring formulation and implementation of a policy framework that ensures sustainable exploitation of marine and coastal resources and integration of mandates that are currently executed by multiple government agencies.

The blue economy policy 2020 aims to work in the following priority areas: fisheries and aquaculture, maritime trade and infrastructure, energy, tourism as well as marine and maritime governance. Through the implementation of this policy, Zanzibar has the opportunity to increase employment, improve the balance of trade, promote food and nutritional security and maintain environmental resilience. Subsequently, by 2030, given the effective operationalization of the policy, we expect Zanzibar to be the leading hub for blue economy activities in the Western Indian Ocean region.

The implementation of the blue economy policy is expected to result in greater involvement of Zanzibaris in wealth and job creation, promote economic growth, social inclusion, and improvement of livelihoods while at the same time ensuring environmental sustainability. The success of this policy will to a large extent depend on the ability of the private sectors to translate opportunities, which the implementation of this policy will provide, into tangible outputs.

Establishment of newly Ministry responsible for Blue Economy and Fishery paves a great way for Zanzibar to fully implement the Blue Economy Policy and coordinates activities there within. With these Zanzibar Government initiatives on harnessing the blue economy through different sectors, Zanzibar economic development will be prospered.

\subsection{LEGAL FRAMEWORK OF THE BLUE ECONOMY}

Blue economy activities are controlled by various laws and regulations (i.e national, regional and international). Government Departments and agencies have been given different mandates resulting in conflict of interest and poor governance due to lack of cooperation between the oversight agencies, compartmentalization and management. This leads to duplication of resources without clear goals of achieving a sustainable blue economy.

To achieve integrated approach and improved governance, the use of Integrated National Maritime Policy as a tool would offer solutions to oversee overarching issues that arose in the institutional, legal and regulatory regimes with a view of providing amicable solutions for the successive implementation of sustainable blue economy.

As Blue Economy cuts across various sectors and industries, this presents ample opportunity for naturally instituting an integrated legal and regulatory frameworks. However, some critical enablers that support an integrated system may be absent due to incoherent policies, weak political will, inefficient enforcement capability, or poor coordination amongst others (Folami, 2017). While these constraints exist, the Blue Economy inherently has potentials to establish linkages across sectors and catalysing inter-sectoral reforms for filling existing gaps in the institutional and legal frameworks. Moreover, this potential could be witnessed at global, regional and national levels (Chircop et al., 2016).

Within the confines of international law and the established legal regime for the rights, jurisdictions and responsibility of states parties on issues relating to the peaceful use of oceans, is the United Nations Convention on the Law of the sea (UNCLOS). It was adopted in 1982 but entered into force in 1994 outlining rights and obligations of states in carrying out activities in the oceans and seas (DOALOS, 2010). It answers the critical legal questions on the delineation of maritime zones and the extent of the territorial boundaries of adjoining coastal states. It also highlights other provisions, including- the exploitation of the living resources within the sea column and the exploration of non-living resources within the seafloor, the obligation for the protection and preservation of the marine environment, provisions on the transfer of marine technology, marine scientific research amongst others.

With a view to addressing arrays of issues, the legal framework within UNCLOS also provides for the adoption of other relevant agreements as complements to the convention. To this end, there were two agreements- firstly, the 1994 Agreement Relating to the implementation of Part XI of the Conventions of the Law of the Sea which relates to the exploitation and exploration of the resources in the international seabed area (Known according to the Convention as "the Area"), considered as the "common heritage of mankind" in section 2, Article 136 (UNCLOS, 1984, p. 70). 
According to UNCLOS, the regulation of the activities in the Area is vested on the International Seabed Authority (ISA) as an institution with this unique mandate (Zacharias, 2014). The other important agreement was the 1995 Agreement for the Management of Straddling Fish Stocks and Highly Migratory Fish Stocks (Also called, the United Nations Fish Stock Agreement), which provides guidelines and directions for the regional cooperation of parties on the management of fisheries and sustainable exploitation of the resources within the Exclusive Economic Zones (EEZ) and the high seas.

The Deep Sea Fisheries Management and Development Act, 2020, provides an important legal framework for Zanzibar's Blue Economy policy implementation. It provides among others, on how the EEZ can be explored, facilities, incentives and scrutiny for its management.

As a supplement to UNCLOS, other equally binding international conventions and agreements exist within the broader legal frameworks of ocean governance regimes and conservation of marine ecosystems. Some of these include- the Convention on Biological Diversity (CBD) and Jakarta Mandate; Paris COP 21 Agreement; Convention on Wetlands of International Importance (Ramsar Convention); Convention for the Protection, Management and Development of the Marine and Coastal Environment of the Eastern African Region (Nairobi Convention); International Convention for the Prevention of Pollution from Ships (MARPOL); World Heritage Convention; Africa Convention on the Conservation of Nature and Natural Resources; Africa Maritime Transport Charter amongst others (Folami, 2017).

Recently, there is a new development following a resolution of the United Nations General Assembly (UNGA) through Resolution 69/292 of 19 June 2015 which relates to developing an International Legally Binding Instrument (ILBI) under UNCLOS on the conservation and sustainable use of Marine Biodiversity in Areas Beyond National Jurisdiction (ABNJ) (Konrad, 2017).

The development of legal and institutional frameworks is obviously still an ongoing process. However, there exists sufficient international legal and institutional regimes that allow for the integration of Blue Economy paradigms into existing hard and soft law instruments. This would aid towards the coordination and harmonization of efforts on implementation of Blue Economy plans in Zanzibar.

\section{RECOMMENDATIONS}

The Zanzibar success and future of the blue economy sustainability must lie in proper policy making and effective implementation, by ensuring continuous monitoring and evaluation with a view to address the emerging challenges in the maritime sectors in the wake of the recent technological changes in the maritime sectors. This study informs policy making that will ensure sustainability of the blue economy so as to unlock full potential of the blue economy in Zanzibar.

There is a need to make sure that economic activities do not harm marine environments and ecosystems. Blue Economy experiences of other countries could be the guiding lessons for Zanzibar. For Zanzibar, there is a need to have on place a national plan that will outline the roadmap for Blue Economy initiatives across sectors. The formulation process of such policy has to be participatory and inclusive. Besides, the government needs to formulate laws, regulations and guiding principles that will facilitate the Blue Economy industries.

Given the broad nature of Blue economy, coordination within and among the various government organs is also crucial. Since the idea of Blue Economy is new in Zanzibar, capacity building across the sectors as well as local community is most essential. In this regard, focusing on education, research and innovation needs to get priority. Prioritizing higher education and better research facilities is very potential for the sake of utilizing sea and marine environmental resources for the economic development of the country.

Zanzibar needs to have a strategic plan that will act as a useful tool for preparation of skilful human resources for maritime sectors. An economy can never be successfully established until it is cultivated and shaped from the root level. Therefore, the government's initiative to establish a Maritime University was a significant decision. Lacking indigenous expertise and funds, Zanzibar has to seek partnership with development partners to develop its marine sector. It can continue pursuing blue diplomacy and take lead in Blue Economy initiatives in Zanzibar.

Also, much attention should be focused on climate change impacts on marine and coastal resources. This will provide ground for the government actors to initiate possible and reliable measures for the current and expected future climate change impacts. Special focus is required on energy efficiency, marine and coastal biodiversity, ecosystem based adaptation, environmental resilience building in the coastal areas, ecosystem restoration, building economic resilience and policy formulation for climate change resilient Blue Economy development.

Achieving these goals and priorities is difficult and requires time. Nevertheless, the goodwill of the government exhibits that Zanzibar is on the right track. The establishment of legal and regulatory documents that would be guiding the sector hence the Zanzibar Government should prioritize it in its national agenda through legislation and legal implementation. 


\section{References}

Chircop, A., Dzidzornu, D., and Oguamanam, C. (2016). Ocean law reform : A MultiLevel Comparative Law Analysis of Nigerian Maritime Zone Legislation. Marine Policy 67: 60-75.

DOALOS (Division for Ocean Affairs and the Law of the Sea) (2010), Current Status of the Convention.

Fernández-Macho, J., González, P., and Virto, J. (2016) An index to assess maritime importance in the European Atlantic economy. Marine Policy 64: 72-81

Folami, Folami Olalekan. (2017). Towards an integrated ocean governance regime and implementation of the Sustainable Development Goal 14 in Nigeria. World Maritime University MSc. Dissertations.592.

Keen, M. R., Schwarz, A.-M., \& Wini-Simeon, L. (2017). Towards defining the Blue Economy: Practical lessons from Pacific Ocean governance. Marine Policy doi:http://dx.doi.org/10.1016/j.marpol.2017.03.002 Retrieved from http://www.sciencedirect.com/science/article/pii/S0308597X16308235.

Kelleher, K. (2015). Building the Blue Economy in the Western Indian Ocean. Presented at the 8th Conference of Parties Meeting for the Nairobi Convention, June 2015.

Llewellyn, L.E., English, S. and Barnwell, S. (2016). A roadmap to a sustainable Indian Ocean blue economy. Journal of the Indian Ocean Region, 12 (1), pp52-66.

Manning, E. (2016). The Challenge of Sustainable Tourism in Small Island Developing States. [Online] Available At: http://canadiancor.com/challenge-sustainable-tourism-small-island-developing-states-sids/ [Accessed 10 March 2019].

Mulazzani, L., Trevisi, R., Manrique, R. and Malorgio, G. (2016), "Blue growth and the relationship between ecosystem services and human activities: the Salento artisanal fisheries case study", Ocean and Coastal Management, Vol. 134, pp. 120-128.

Park, D., Seo, K., Kildow, D. and Judith, T. (2014). Rebuilding the classification system of the ocean economy. Journal of Ocean and Coastal Economics, 2014 (1), p4

Rahman, Mohammad. (2017). Blue Economy and Maritime Cooperation in the Bay of Bengal: Role of Bangladesh. Procedia Engineering. 194. 356-361. 10.1016/j.proeng.2017.08.157.

Schoolmeester, T., Baker, E., Fabres, J., Halvorsen, Ø., Lønne, Ø., Poussart, J.N., Pravettoni, R., Sørensen, M. and Thygesen, K. (2009), Continental Shelf: The Last Maritime Zone, UNEP/GRID-Arendal, Norway.

Senaratne, Malshini \& Zimbroff, Andrew. (2019). The Blue Economy in the Indian Ocean. A Literature Review. 1. 121-146.

Subhan, A. (2018). India and Indonesia are growing the Blue Economy. The Asian Post (31 May 2018):https://theaseanpost.com/article/india-and-indonesia-are-growing-blue-economy.

Toropova, C., Meliane, I., Laffoley, D., Matthews, E. and Spalding, M. (2010), Global Ocean Protection: present Status and Future Possibilities, IUCN.

United Nations Convention on the Law of the Sea (UNCLOS), adopted 10 December 1982, entered into force 16 November 1994, 1833 UNTS 397 (LOS Convention).

UNDP (2018). Blue Economy, Community Solutions; UNDP: New York, NY, USA, 2018; pp. 1-60.

UNDP (2018). Policy brief an input to Sustainable Blue Economy Conference hosted jointly by Kenya and Canada in Kenya, 26-28 November 2018

United Nations (2014) United Nations Blue Economy Concept Paper. Available at https://sustainabledevelopment.un.org/concent/documents/2978BEconcept.pdf (Accessed 20th June 2019).

United Nations Conference on Trade and Development (UNCTAD). (2014). The Oceans Economy: Opportunities and Challenges for SIDS. [Online] Available at: https://unctad.org/en/PublicationsLibrary/ditcted2014d5_en.pdf.

United Nations Economic Commission for Africa. (2016). Africa's blue economy: a policy handbook. UNECA.

Voyer, M. et al. (2018). Maritime security and the Blue Economy: intersections and interdependencies in the Indian Ocean. Journal of the Indian Ocean Region 14 (1), pp28-48.

Warner, R., \& Schofield, C. H. (2012). 